\title{
THE ACTION OF SODIUM CHLORIDE, AMMONIUM CHLO- RIDE, AND SODIUM BICARBONATE ON THE TOTAL ACID-BASE BALANCE OF A CASE OF CHRONIC NEPHRITIS WITH EDEMA
}

By FULLER ALBRIGHT' ${ }^{1}$ AND WALTER BAUER ${ }^{2}$

(From the Metabolism Ward of the Massachusetts General Hospital, Boston)

(Received for publication January 14, 1929)

\section{INTRODUCTION}

The steps in the clarification of the pathological physiology associated with the edema in the nephrotic type of chronic nephritis form an interesting and as yet unfinished chapter in modern medicine. In 1902 Widal (1) pointed out that the failure to excrete water is associated with a difficulty in excreting sodium chloride and advocated a low salt diet. In 1909 Blum (2) amplified this by showing that it is only the sodium ion which the kidney has difficulty in excreting. In 1911 Meyer and Cohn (3) observed the diuretic action of calcium chloride in infants, and in 1918 Schultz (4) used this drug in treating war nephritis. Blum, Aubel, and Hausknecht (5) in 1922 thought that the liberation of edema following the administration of calcium chloride is the result of an antagonism between calcium and sodium which facilitates the excretion of sodium. A year later Haldane, Hill, and Luck (6) reported the production of an acidosis by the ingestion of calcium chloride and attributed its diuretic action to this. In the same year Gamble, Ross, and Tisdall (7) showed that this acid effect is due to a greater absorption of the chlorine ion than of the calcium ion. In the meantime, Haldane (8) in 1921 had demonstrated that the ingestion of ammonium chloride produces an acidosis. This he attributed to the transformation of the ammonia into urea, which leaves the acid radicle chlorine to unite with body base. In

${ }^{1}$ Research Fellow, Massachusetts General Hospital and Harvard Medical School.

${ }^{2}$ Medical Resident, Massachusetts General Hospital. 
1923, Keith, Barrier, and Whelan (9) drew attention to the diuretic action of ammonium chloride in nephritis with edema. Finally in 1925, Gamble, Blackfan, and Hamilton (10) showed that calcium chloride and ammonium chloride bring about a diuresis by producing an acidosis. They pointed out that in order to excrete the chlorine ion there must be a corresponding increase in the titratable acidity of the urine and in the excretions of ammonia and total base. The first two of these factors do not increase sufficiently to take care of the increased chlorine excretion, and therefore base is withdrawn from the body fluids. This base they found to be sodium and potassium. With the increased excretion of base, the water held by the base in the body is liberated, and diuresis results. This excellent paper practically limits the possibilities for clarification in this direction but leaves two things to be explained. What is the cause of the original difficulty in excreting base? Granted that acid salts act by making necessary an increased excretion of base to prevent severe acidosis, what is the exact physiological means by which they accomplish this? In other words, we cannot be content with the explanation that the body has to excrete base when an acid salt is taken. We should like to know just how this is brought about.

An entirely different approach to this question starts with the work of Epstein (11) (12) who emphasized the low albumin of the serum, the low protein content of edema and ascitic fluid, and the high fat content of the blood as indicated by the high cholesterol. He believed that the hypoproteinemia is the basic disorder and directed his treatment toward the relief of this. Salvesen and Linder (13) in 1923 showed that with the lowered serum protein in nephritis there is a corresponding lowered serum calcium, and that the calcium content of various body fluids bears a definite relation to the protein content. Recently Blackfan and Hamilton (14) have made what is probably a very significant contribution when they demonstrated a low concentration of total base in the serum of children suffering with nephrosis.

In summary, we have a condition associated with massive albuminuria, a resulting low serum albumin, a low serum calcium dependent on the low serum protein, a low serum total base possibly also dependent on the low serum protein, a difficulty in excreting base in the urine, a resulting accumulation of base in the tissues, a retention of 
water to keep the relation of base to water in the body fluids constant, and hence edema.

The present investigation was undertaken in order to test the validity of the above concept, and to discover, if possible, additional relations.

\section{EXPERIMENTAL DATA}

A patient with relatively mild, almost stationary, and essentially uncomplicated "nephrosis" was selected who was willing to coöperate in this rather tedious investigation. The details of the clinical history are appended. In brief, she was an adult woman with massive albuminuria, marked edema, low serum albumin, high blood cholesterol, normal renal function as shown by the excretion of phenolsulphophthalein, normal blood non-protein nitrogen, normal urinary sediment, and normal blood pressure.

She was transferred to the Metabolism Ward where she was studied for twelve three-day metabolism periods. During this entire time (36 days) she received a carefully weighed $\operatorname{diet}^{3}$ containing exactly the same articles of food every day. Likewise, the same amount of fluid was administered every day at the same hours. She was allowed out of bed for exactly the same amount of time every day. The urine and feces were collected in three day periods for analysis. Venous blood for analysis was withdrawn under oil at frequent intervals. All determinations were made on serum.

The urine was analyzed for what we have termed "titratable acidity minus $\mathrm{CO}_{2}$," ammonia, total base, calcium, phosphorus, sulphates, chlorine, protein, nitrogen, and non-protein nitrogen; the feces for calcium, total base, and phosphorus; the serum for total base, calcium, protein, albumin, globulin, $\mathrm{CO}_{2}$ combining power, chlorine, and phosphorus. The methods employed in the collection of the excreta, the preparation of the diet, and the analyses of the serum, urine, and feces have been given in a previous paper (15). The titratable acidity minus $\mathrm{CO}_{2}$ and the ammonia were analyzed daily. The value of the former expression was obtained by adding a known amount of acid to the urine, shaking until the $\mathrm{CO}_{2}$ was entirely driven off, and then

${ }^{3}$ The details of the diet are appended. 
titrating back to a $\mathrm{pH}$ of 7.35. The amount of alkali minus the amount of acid added equals the "titratable acidity minus $\mathrm{CO}_{2}$." In an alkaline urine this may become a negative expression.

The investigation consisted of a sequence of three control periods (9 days), two in which salt was added to the diet, two in which this was replaced by ammonium chloride, one control period, one in which sodium bicarbonate was administered, and finally three control periods.

\section{RESULTS}

\section{A. Total base $e^{4}$ metabolism (See table 1 and chart 1)}

In chart 1 there are given graphically the data for the total base exchange, the output of urine, and the body weight. Since body fluids contain approximately the base equivalent of $150 \mathrm{cc}$. of $\mathrm{N} / 10$ base per $100 \mathrm{cc}$. (16), the retention of $150 \mathrm{cc}$. of N/10 base should be associated with the retention of $100 \mathrm{cc}$. of fluid and a gain in weight of 100 grams. This of course is true, provided the patient is in nitrogen balance. (An insignificant error enters into this reasoning due to the deposit of base as calcium in the bones). Therefore, in chart 1 the scale for the weight is chosen such that 1000 grams on the weight scale is equivalent to $1000 \mathrm{cc}$. of $\mathrm{N} / 10$ base on the base scale. Likewise, the urine is charted on a scale of the same size as the weight.

An examination of chart 1 shows that, during control periods 1, 2, and 3 on a low base intake, the patient was approximately in total base equilibrium and that the weight and urinary output were almost stationary. During periods 4 and 5, in spite of a marked increase in the total base intake, due to the ingested sodium chloride, there was no increase in the total base output except for a slight rise in the urinary base in period 5. The entire added base was retained in the body; the body weight rose and the amount of urine decreased. During periods 6 and 7 , when the chlorine was added in the form of ammonium chloride instead of sodium chloride, there was a marked increase in total base excretion with a negative total base balance and a corresponding increase in output of urine and decrease in body weight. In control period 8 there was a return to equilibrium. During period 9,

\footnotetext{
${ }^{4} \mathrm{By}$ total base is meant the sum of calcium, magnesium, sodium, and potassium expressed in cubic centimeters of $\mathrm{N} / 10$.
} 
when the base was administered in the form of sodium bicarbonate in place of sodium chloride, there was a marked rise in the total base

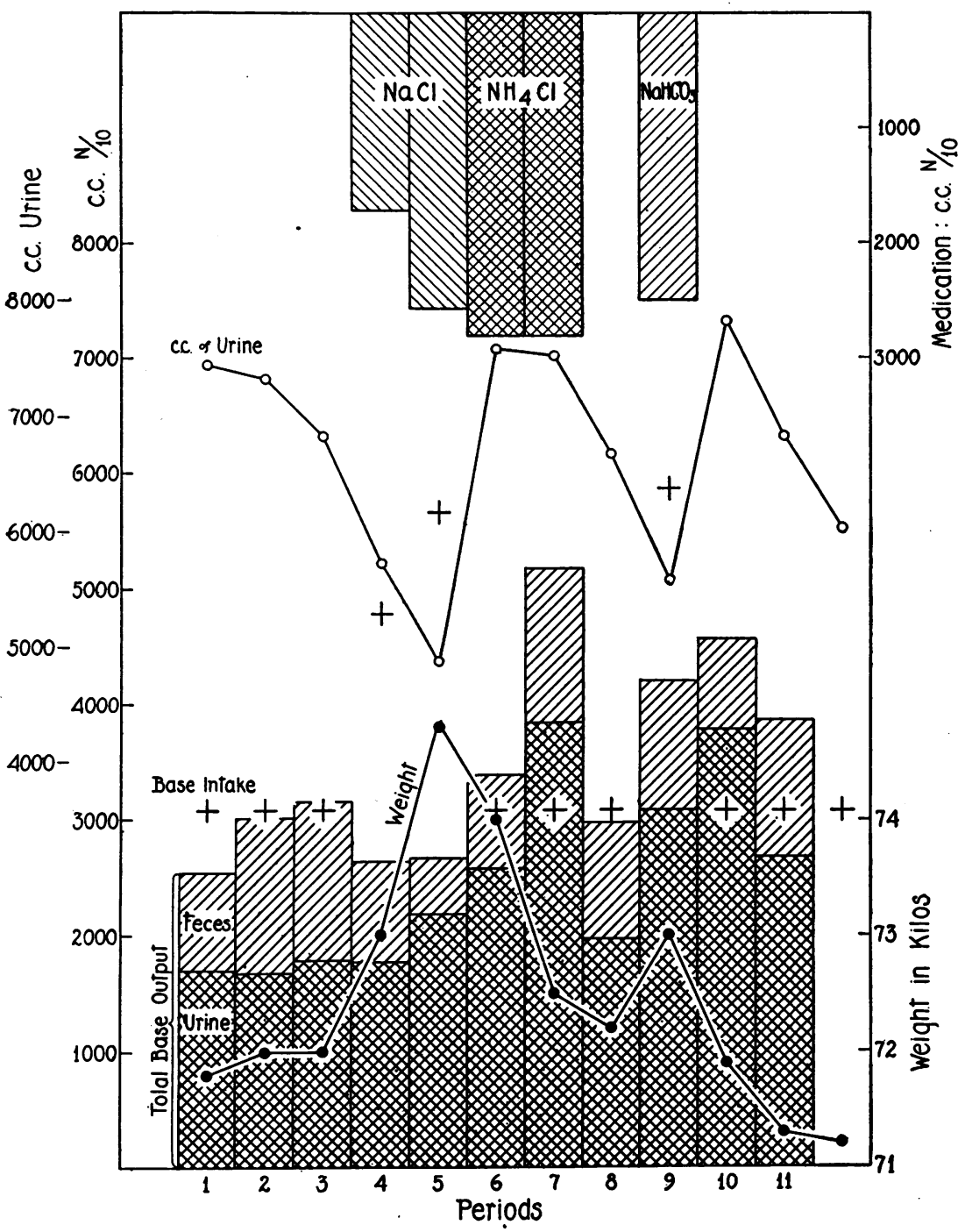

Chart 1. Graphic Representation of Data from Table 1

excretion, not, however, equal to the increased total base intake. Corresponding to the retained base, there was a decrease in output of 
urine and an increase in weight. In control period 10, the increased base excretion continued. During period 11, equilibrium was again reached. From the last two columns of table 1 it will be noted that the change in weight from period to period corresponded extremely well with the change in weight as calculated from the total base balance.

TABLE 1

The data for the total base balance, output of urine and body weight for the 36 days of observation

It will be noted that the actual change in weight from period to period corresponds extremely well with the change in weight as calculated from the total base balance.

\begin{tabular}{r|r|r|r|r|r|r|r|r|r|r}
\hline & \multicolumn{5}{|c|}{ Total base } & & & & \\
\hline \\
\cline { 2 - 2 }
\end{tabular}

From the data thus far, the following points seem significant.

1. Gains and losses of edema fluid could be approximately predicted from the total base balances on the supposition that $100 \mathrm{cc}$. of tissue fluids are equivalent to $150 \mathrm{cc}$. of N/10 base.

2. Addition of the neutral salt sodium chloride for a period of six days resulted in an almost quantitative retention of the added base.

3. In spite of inability to excrete base, the absorption of sodium chloride was quantitative.

4. Addition of the acid-producing salt, ammonium chloride, increased the total base excretion in the urine and this increase was 
more marked during the second three days than during the first three days. This effect stopped immediately on cessation of the drug.

5. Addition to the diet of the alkaline salt, sodium bicarbonate, increased the total base excretion but not sufficiently to offset the increased base intake. This increased excretion continued and even increased during the first control period following the sodium bicarbonate period.

TABLE 2

Data showing the calcium and phosphorus balances

\begin{tabular}{|c|c|c|c|c|c|c|c|c|c|}
\hline \multirow{2}{*}{ Period } & \multicolumn{4}{|c|}{ Calcium } & \multicolumn{4}{|c|}{ Phosphorus } & \multirow{2}{*}{ Medication } \\
\hline & Intake & Urine & Feces & Balance & Intake & Urine & Feces & Balance & \\
\hline & $\begin{array}{l}c c . \text { of } \\
N / 10\end{array}$ & $\begin{array}{l}\text { cc. of } \\
N / 10\end{array}$ & $\begin{array}{l}\text { cc. of } \\
N / 10\end{array}$ & $\begin{array}{l}\text { ce. of } \\
\text { N/10 }\end{array}$ & $\begin{array}{l}c c . o f \\
N / 10\end{array}$ & $\begin{array}{l}\text { cc. of } \\
N / 10\end{array}$ & $\begin{array}{l}c c .0 f \\
N / 10\end{array}$ & $\begin{array}{l}c c . \text { of } \\
N / 10\end{array}$ & cc. of $N / 10$ \\
\hline 1 & 154 & 17 & 208 & -71 & 1,885 & 1,275 & 496 & +114 & \\
\hline 2 & 154 & 18 & 250 & -114 & 1,885 & 1,022 & 774 & +89 & \\
\hline 3 & 154 & 36 & 228 & -110 & $\mid 1,885$ & 990 & 703 & +192 & \\
\hline 4 & 154 & 19 & 153 & -18 & 1,885 & 2,270 & 502 & -887 & 1,710 of $\mathrm{NaCl}$ \\
\hline 5 & 154 & 28 & 129 & -3 & 1,885 & 1,179 & 624 & +82 & 2,565 of $\mathrm{NaCl}$ \\
\hline 6 & 154 & 77 & 146 & -69 & $\mid 1,885$ & 1,445 & 504 & -64 & 2,800 of $\mathrm{NH}_{4} \mathrm{Cl}$ \\
\hline 7 & 154 & 110 & 195 & -151 & 1,885 & 5,120 & 611 & -3846 & 2,800 of $\mathrm{NH}_{4} \mathrm{Cl}$ \\
\hline 8 & 154 & 81 & 147 & -74 & 1,885 & 712 & 425 & +748 & \\
\hline 9 & 154 & 27 & 171 & -44 & 1,885 & 922 & 505 & +458 & 2,500 of $\mathrm{NaHCO}_{3}$ \\
\hline 10 & 154 & 45 & 113 & -4 & 1,885 & 900 & 433 & +552 & \\
\hline 11 & 154 & 32 & 202 & -80 & 1,885 & 1,119 & 596 & +170 & \\
\hline 12 & 154 & 10 & 157 & -13 & 1,885 & & 578 & & \\
\hline
\end{tabular}

\section{B. Calcium and phosphorus metabolism}

It will next be of interest to note the calcium metabolism and to see whether this component of the total base metabolism behaves in any way similar to the total base as a whole. The basic diet was low in calcium and similar to that used in a study of the calcium excretion of normal individuals (17). In that study of thirteen normal men with an average calcium intake of $165 \mathrm{cc}$. of $\mathrm{N} / 10$ calcium per three-day period, there was an average output in the urine of $85 \mathrm{cc}$. of $\mathrm{N} / 10$ calcium, in the feces of $300 \mathrm{cc}$. of $\mathrm{N} / 10$ calcium, making an average negative calcium balance per three day period of $220 \mathrm{cc}$. of $\mathrm{N} / 10$ calcium. 
In control periods 1,2 , and 3 (table 2) it will be noted that the calcium excretion in the urine was strikingly small and that the negative calcium balance on a low calcium diet was likewise small. ${ }^{5}$ The low calcium excretion in nephrosis has been noted by Scriver (18). It will be further noted that ammonium chloride increased the urinary excretion of calcium (periods 6 and 7) whereas Scriver found that parathormone was ineffective in accomplishing this in nephrosis (18).

The ratio of the urinary to the fecal phosphorus excretion suggests that there was no difficulty in excreting phosphorus through the kidneys. The increased phosphorus excretion in the urine, as a result of ammonium chloride, was far out of proportion to the increased calcium excretion, if one were assuming that these were derived from tertiary calcium phosphate from the bones. There was no corresponding breakdown of nitrogen to account for the phosphorus deficit (v. infra). One must conclude that this phosphorus came from phosphorus held in tissue fluids. The increased phosphorus excretion resulting from the ingestion of hydrochloric acid has been discussed by Fitz, Alsberg, and Henderson (20).

The following points from the calcium and phosphorus data seem significant:

6. The urinary calcium excretion was very much lower than that of normal individuals on a similar régime and there was no corresponding increased fecal calcium éxcretion.

7. Ammonium chloride increased the urinary calcium and phosphorus excretions.without affecting that in the feces. The increase in the urinary phosphorus was out of proportion to the increase in the urinary calcium.

\section{Nitrogen metabolism}

Before one can calculate gains in weight as gains in edema fluid (v. supra), it is necessary to know that the subject was in nitrogen equilibrium. Therefore, table 3 and chart 2 have been constructed. It will be noted that on a nitrogen intake of 25.9 grams per period (54 grams of protein a day) the patient was in nitrogen balance.

5 The low urinary excretion in chronic nephritis with edema has been confirmed in two other unpublished cases studied at the Johns Hopkins Hospital in conjunction with Dr. Read Ellsworth. 
This was true in spite of rather large losses of protein in the urine. The protein losses in the urine in this case were smaller than one often finds in similar cases. The nitrogen from the ammonium chloride in periods 6 and 7 appeared almost quantitatively as ammonia in the urine. From this it would appear that the acidosis produced by the conversion of the ammonia into urea, when ammonium chloride is absorbed, may be later compensated for by the reconversion of urea into ammonia when the chlorine is excreted.

TABLE 3

Data showing nitrogen metabolism

\begin{tabular}{c|c|c|c|c|c|c|c}
\hline Period & Intake & $\begin{array}{c}\text { Non- } \\
\text { protein } \\
\text { nitrogen* } \\
\text { in urine }\end{array}$ & $\begin{array}{c}\text { Protein } \\
\text { nitrogen } \\
\text { in urine }\end{array}$ & $\begin{array}{c}\mathrm{NH}_{3} \\
\text { introgen } \\
\text { in urine }\end{array}$ & Fecest & Balance & Medication \\
\cline { 1 - 4 } 1 & grams & grams & grams & grams & grams & grams & cc. of $N / 10$ \\
2 & 25.9 & 18.65 & 4.86 & 0.39 & 2.59 & -0.20 & \\
3 & 25.9 & 20.61 & 6.65 & 0.82 & 2.59 & -3.95 & \\
4 & 25.9 & 18.90 & 4.80 & 0.76 & 2.59 & -0.39 & \\
5 & 25.9 & 17.83 & 4.50 & 0.93 & 2.59 & +0.98 & 1,710 of $\mathrm{NaCl}$ \\
6 & 29.8 & 16.64 & 3.20 & 0.95 & 2.59 & +3.47 & 2,565 of $\mathrm{NaCl}$ \\
7 & 29.8 & 21.82 & 4.59 & 2.09 & 2.98 & +0.74 & 2,800 of $\mathrm{NH}_{4} \mathrm{Cl}$ \\
8 & 25.9 & 17.54 & 5.35 & 5.30 & 2.98 & +0.78 & 2,800 of $\mathrm{NH}_{4} \mathrm{Cl}$ \\
9 & 25.9 & 16.28 & 3.02 & 1.18 & 2.59 & +0.42 & \\
10 & 25.9 & 20.80 & 5.20 & 0.88 & 2.59 & -2.01 & 2,500 of $\mathrm{NaHCO}_{3}$ \\
11 & 25.9 & 20.83 & 4.91 & 1.25 & 2.59 & -2.43 & \\
12 & 25.9 & & & 1.58 & 2.59 & -1.29 & \\
\hline
\end{tabular}

* This is inclusive of ammonia nitrogen which is represented in a separate column. †Fecal nitrogen taken as 10 per cent of nitrogen intake.

From this study of the nitrogen metabolism, the following points seem important:

8. In spite of protein loss in the urine, the patient remained in nitrogen equilibrium on $\mathbf{5 4}$ grams of protein a day.

9. When ammonium chloride was ingested, the ammonia excretion in the urine rose proportionately to the increased intake.

\section{Total acid-base balance of urine}

Table 4 and chart 3 have been constructed in order to study the acidbase balance of the urine during the varying conditions of this inves- 
tigation. In this we have followed the line of approach used by Gamble (19) with a slight modification. This author, by determining

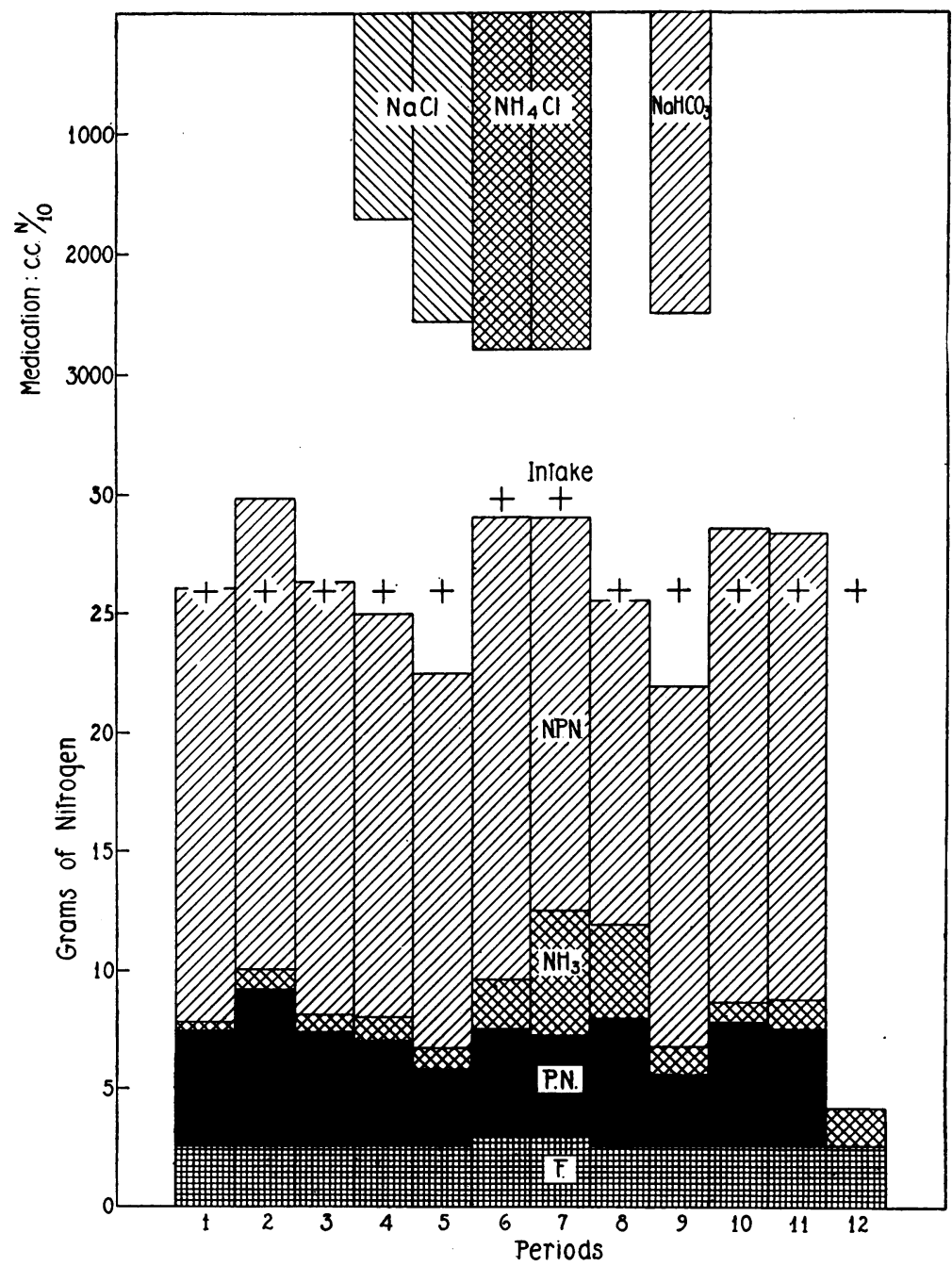

Chart 2. Graphic Representation of Data Shown in Table 3

the titratable acidity of the urine ( $=$ base necessary to bring $\mathrm{pH}$ of urine to 7.35), was able to construct tables and charts in which the 
cations of the urine in one column were balanced by the anions in another. Thus, the sum of total base, ammonia, and titratable acidity, all expressed in cubic centimeters of $\mathrm{N} / 10$ equals the sum of the chlorides, sulphates, phosphates, organic acid and carbonic acid also expressed in cubic centimeters of $\mathrm{N} / 10$ except that a factor has to be

TABLE 4

Data for acid-base balance of the urine during the varying conditions of this investigation

\begin{tabular}{|c|c|c|c|c|c|c|c|c|c|c|c|c|}
\hline \multirow[b]{2}{*}{ 总 } & \multirow{2}{*}{ 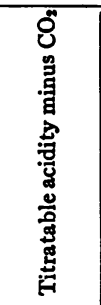 } & \multicolumn{3}{|c|}{ Cations in urine } & \multicolumn{6}{|c|}{ Base bound by anions of urine } & \multirow[b]{2}{*}{ Medication } & \multirow[b]{2}{*}{ 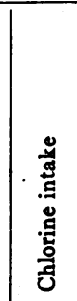 } \\
\hline & & 荟 & 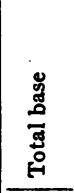 & 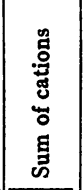 & $\tau$ & \&̊ & 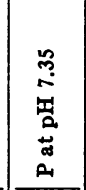 & 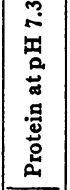 & 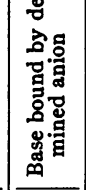 & 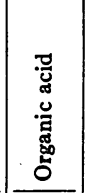 & & \\
\hline & $\begin{array}{l}c c . \text { of } \\
N / 10\end{array}$ & $\begin{array}{l}c c .0 f \\
N / 10\end{array}$ & $\begin{array}{l}c c . \text { of } \\
N / 10\end{array}$ & $\begin{array}{l}\text { cc. of } \\
N / 10\end{array}$ & \begin{tabular}{|l|}
$c c . o f$ \\
$N / 10$
\end{tabular} & $\begin{array}{l}\text { cc. of } \\
\text { N/10 }\end{array}$ & $\mid \begin{array}{l}c c . \text { of } \\
N / 10\end{array}$ & $\left|\begin{array}{|}\mid c c .0 f \\
N / 10\end{array}\right|$ & $\begin{array}{l}c c . \text { of } \\
N / 10\end{array}$ & $\begin{array}{l}c c . \text { of } \\
N / 10\end{array}$ & cc. of $N / 10$ & $\begin{array}{l}c c . \text { of } \\
N / 10\end{array}$ \\
\hline 1 & 41 & 279 & 1,700 & 2,020 & 104 & 404 & 773 & 53 & 1,334 & 686 & & 570 \\
\hline 2 & -21 & 589 & 1,686 & 2,254 & 106 & 470 & 620 & 72 & 1,268 & 986 & & 570 \\
\hline 3 & -47 & 543 & 1,795 & 2,291 & 188 & 463 & 595 & 52 & 1,298 & 993 & & 570 \\
\hline 4 & 163 & 667 & 1,782 & 2,612 & 313 & 410 & 1,370 & 49 & 2,142 & 470 & $\begin{array}{c}1,710 \text { of } \\
\mathrm{NaCl}\end{array}$ & 2,370 \\
\hline 5 & 400 & 683 & 2,178 & 3,261 & 1,008 & 358 & 709 & 35 & 2,110 & 1,151 & $\begin{array}{c}2,565 \text { of } \\
\mathrm{NaCl}\end{array}$ & 3,260 \\
\hline 6 & 652 & 1,492 & 2,569 & 4,713 & 3,280 & 451 & 864 & 50 & 4,645 & 68 & 2,800 of & 3,370 \\
\hline 7 & 684 & 3,785 & 3,890 & 8,359 & 4,813 & 371 & 3,070 & 46 & 8,300 & 59 & 2,800 of & 3,370 \\
\hline 8 & 468 & 2,787 & 1,966 & $\mid 5,211$ & 2,058 & 358 & 428 & 58 & 2,902 & 2,309 & & 570 \\
\hline 9 & $-1,008$ & 843 & 3,083 & 2,918 & 546 & 318 & 554 & 33 & 1,451 & 1,467 & $\begin{array}{l}2,500 \text { of } \\
\mathrm{NaHCO}_{3}\end{array}$ & 570 \\
\hline 10 & $-1,017$ & 630 & 3,775 & 3,388 & 716 & 477 & 540 & 56 & 1,789 & 1,599 & & 570 \\
\hline 11 & -57 & \begin{tabular}{|l|} 
\\
\end{tabular} & 2,675 & 3,515 & 848 & 444 & 720 & 53 & 2,065 & 1,450 & & 570 \\
\hline 12 & 202 & 1,134 & & & & 470 & & & & & & 570 \\
\hline
\end{tabular}

introduced for the phosphates, which at the $\mathrm{pH}$ of 7.35 bind only 1.8 equivalents of base rather than 3 .

We have modified this scheme in that both our cation and our anion columns are shorter by the carbonic acid value, i.e., on the cation side our third value is the "titratable acidity minus $\mathrm{CO}_{2}$ " instead of the titratable acidity, and on the anion side we have omitted the 


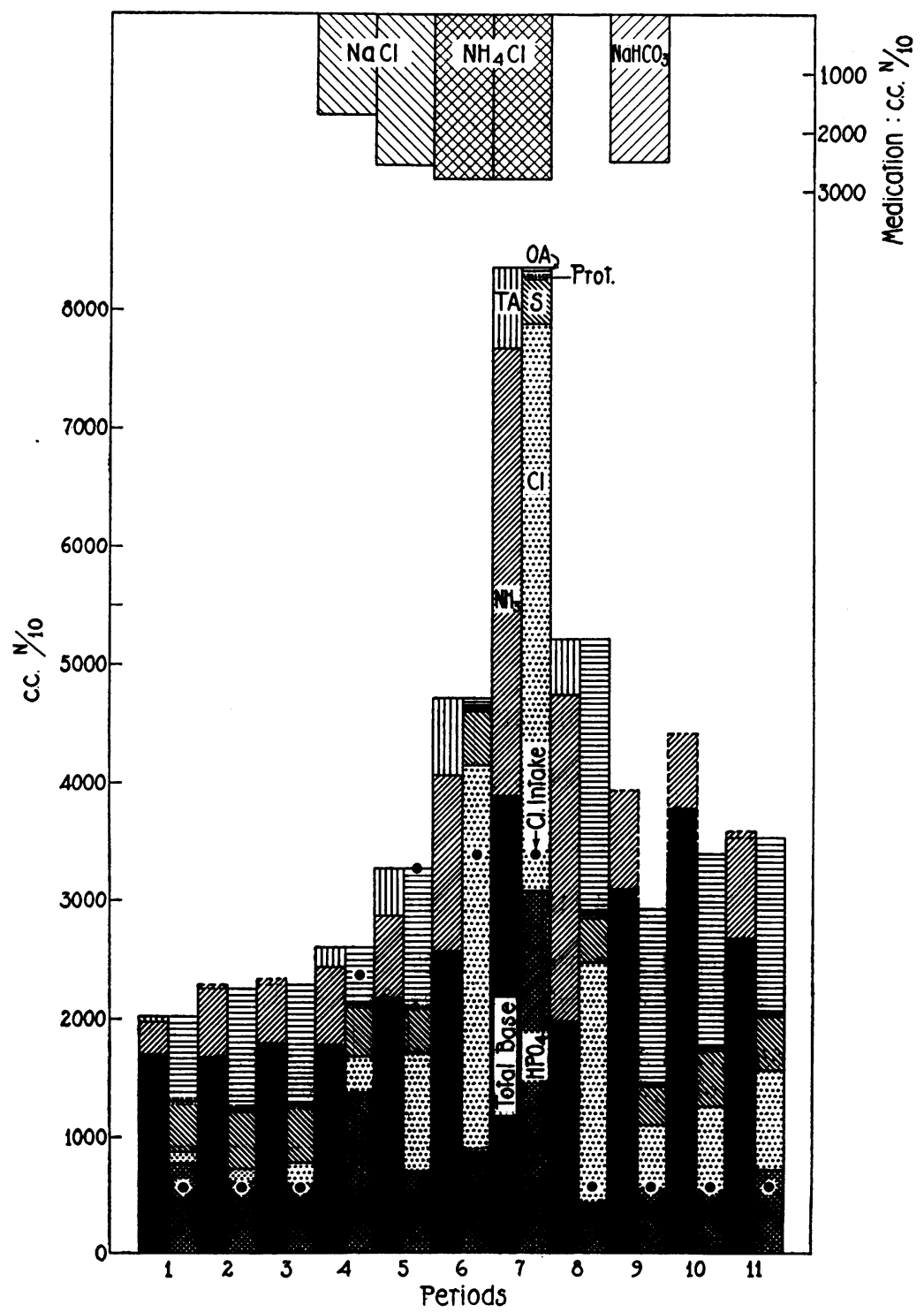

Chart 3. Graphic Representation of Data Shown in Table 4 
carbonic acid. We have not estimated the organic acids but have assumed this to be represented by the difference between the cation column and the sum of the other anions. Such values for the organic acids contain the errors of all the determinations. In addition, because of the large amount of protein in the urine, we have attempted to ascertain the base-binding value of this at $\mathrm{pH} 7.35$ by using the formula of Van Slyke, Wu and McLean (21) for base bound by serum protein,

$$
B P=0.68 P_{s}(\mathrm{pH}-4.80)
$$

in which $B P$ and $P_{s}$ represent respectively cubic centimeters of $\mathrm{N} / 10$ base per $100 \mathrm{cc}$. of serum combined with protein, and per cent of protein in the serum. We appreciate that any value for base bound by urine protein thus obtained is extremely inaccurate, especially as the protein is mostly albumin rather than a mixture of albumin and globulin.

It is of interest to compare the chlorine excretion in the urine with the chlorine intake (see last column in table 4). During the control periods $1 ; 2$ and 3 the urinary excretion of chlorine was very low, about $\frac{1}{4}$ of the intake. During the sodium chloride periods the urinary excretion went up, but very much less than the intake. This does not show an inability to excrete chlorine but merely represents the retention of chlorine necessary for offsetting the retained base. In the ammonium chloride periods, the urinary excretion of chlorine exceeded the intake, which was to be expected. The excess represents the chlorine held by the base in the edema fluid. The increased chlorine excretion continued into control period 8. During the sodium bicarbonate period the urinary chlorine was again reduced, probably because chlorine was again withheld to offset the withheld base. During control periods 10 and 11 the excretion again rose above the intake concomitant with the loss of edema fluid.

In chart 3 , during control periods 1,2 , and 3 it will be noted that the "titratable acidity minus $\mathrm{CO}_{2}$ " was small or negative. During the sodium chloride period the anion columns were increased due to a rise in the chlorine and phosphorus excretion. This was compensated for in the cation column by a rise in the "titratable acidity minus $\mathrm{Co}_{2}$ " and a rise in the ammonia. During the ammonium chloride periods the anion columns were very much increased due to 
the marked increase in the chlorine and phosphorus excretions. This was compensated for on the cation side by a marked increase in all components. In control period 8.the findings still showed the effect of period 7, but it will be noted that the total base excretion was the first of the cation components to return to its previous level. This rather suggests that total base excretion in response to an acid is a last line of defense and only takes place after the ammonia mechanism and the titratable acidity have been taxed to their limits. During the sodium bicarbonate period, the "titratable acidity minus $\mathrm{CO}_{2}$ " became a negative quantity due to the large amount of $\mathrm{CO}_{2}$. In this period and the following period it would appear that anions were in demand to neutralize cations which were being excreted in excess, whereas in the ammonium chloride periods, the exact opposite was the case. In other words, the increased excretion of base as a result of ammonium chloride ingestion may be thought of as an effort on the body's part to ward off fatal acidosis; whereas the increased excretion of base as a result of sodium bicarbonate is an indication that the kidneys in this case can excrete base under certain conditions.

The figures for the organic acid excretions are of interest, although it must be repeated that they contain all the errors of this investigation. They showed little of interest during the first five periods. During the ammonium chloride period there was a marked decrease in organic salt excretion, possibly because base was at a premium and it was more important to excrete the mineral acid chlorine. The increased organic acid excretion in the following control period may represent this stored organic acid. During the sodium bicarbonate period and the period following, the organic acid excretions were high, possibly because anions were in demand for excretion with the base.

From table 4 and chart 3 the following observations seem significant:

10. Provided that it was not being withheld to offset the retained fixed base, chlorine was readily excreted.

11. When additional sodium chloride was ingested, the sodium was entirely retained; part of the chlorine was withheld to offset the sodium; the rest of the chlorine was excreted in the urine with a resulting rise in the titratable acidity and the ammonium excretion. 
12. Addition of ammonium chloride caused a marked rise in the chlorine and phosphorus excretion and this was offset by a rise in all the cation components of the urine.

13. The increased excretion of fixed base after ingestion of acid tended to occur only after other mechanisms for the neutralization of acids had been thoroughly taxed.

14. The increased excretion of fixed base after alkali ingestion apparently depended on a primary increased ability to excrete base.

TABLE 5

Data for serum electrolytes obtained at various times during this investigation

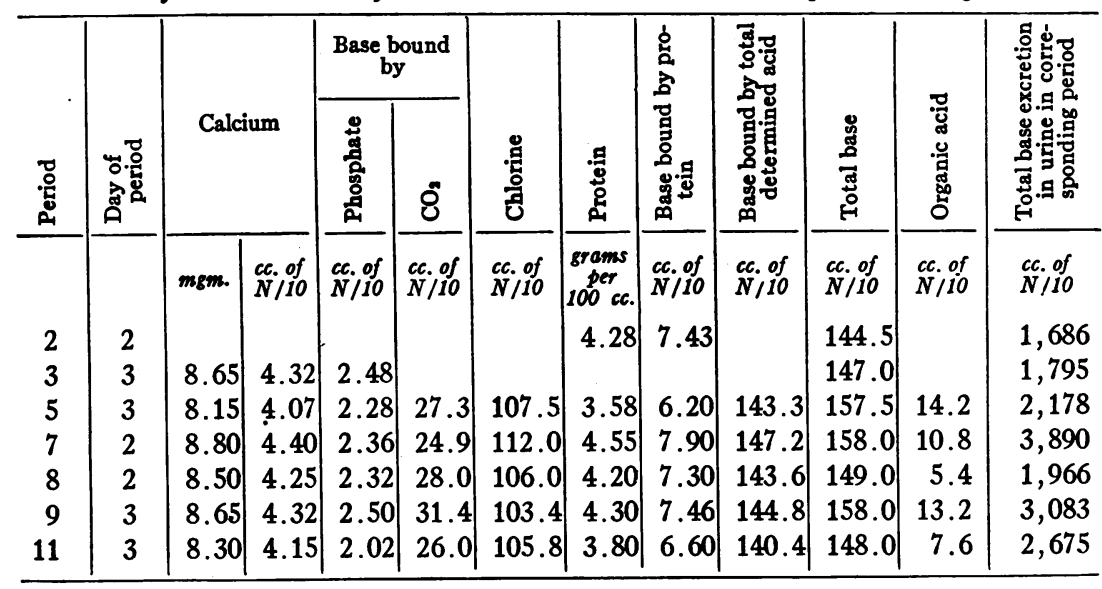

15. Organic acids apparently were retained in the body when base was at a premium and were excreted in excess when acid was at a premium.

\section{E. Serum electrolytes}

The serum findings are shown in table 5 and chart 4 (q. v.). All values are on serum. In determining the base bound by protein we used the formula of Van Slyke, Wu, and McLean (v. supra) and assumed a $\mathrm{pH}$ of 7.35. The objections to this formula have been discussed by Peters, Bulger, Eisenman and Lee (22), but it offers an approximation which is probably satisfactory for comparative pur- 
poses. Base as $\mathrm{BHCO}_{3}$ was calculated by the equation of Peters, Bulger, Eisenman and Lee (22)

$$
B=\frac{\mathrm{CO}_{2}-2.85}{2.24}
$$

where 2.85 volumes per cent is equal to the amount of $\mathrm{CO}_{2}$ dissolved in serum at $40 \mathrm{~mm}$. of $\mathrm{CO}_{2}$ tension and $38^{\circ} \mathrm{C}$. The phosphorus in milligrams per $100 \mathrm{cc}$. was reduced to cc. of $\mathrm{N} / 10$ per $100 \mathrm{cc}$. by the

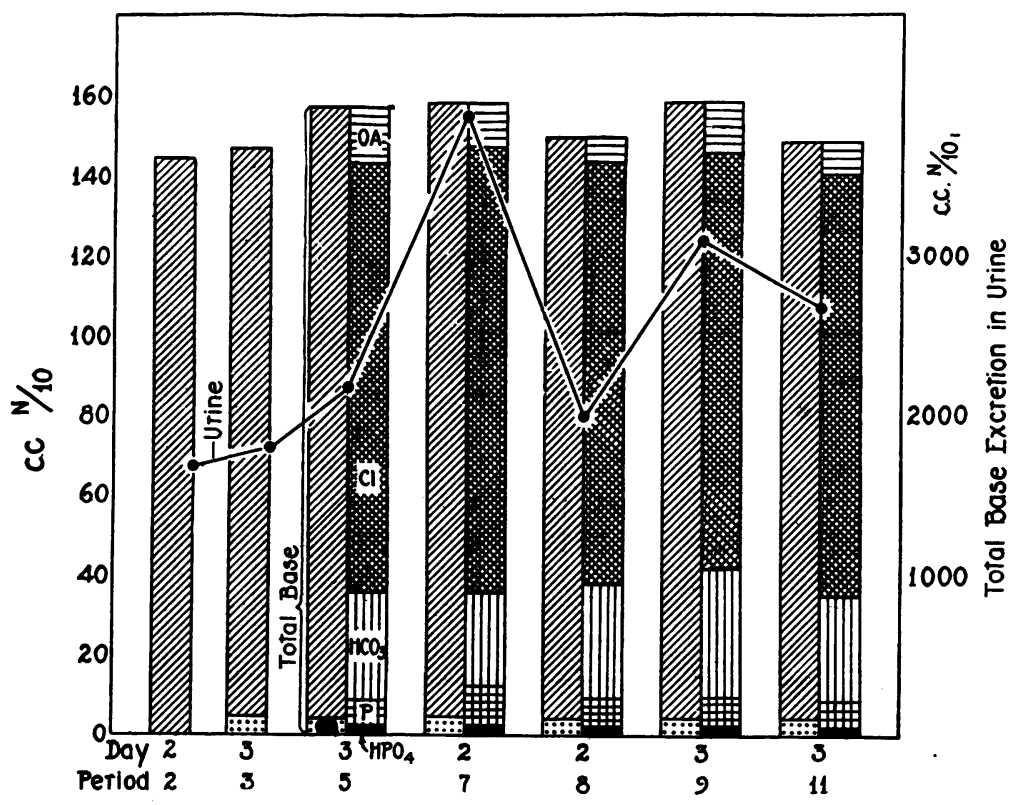

Chart 4. Graphic Representation of Data Shown in Table 5

factor 1.8/3.1, accepting L. J. Henderson's (23) estimate of the proportion of primary and secondary phosphate in the blood. The difference between the sum of the base bound by the determined acid and the total base we have termed "organic" acid, but sulphates are included also as a component of this value.

The serum calcium was definitely low by about $1.5 \mathrm{mgm}$. without any corresponding rise in serum phosphorus. This is undoubtedly due to the low serum protein as pointed out by Salvesen (13). The serum total base was likewise low during control periods $2,3,8$, and 
11. This supports the work of Blackfan and Hamilton (14). These authors give the normal range of serum total base as 154 to $161 \mathrm{cc}$. of $\mathrm{N} / 10$ base. It is of interest that this lowered base value rose to normal during the latter part of the sodium chloride ingestion, during the ammonium chloride period, and during the sodium bicarbonate period. When the total base value of the serum is compared with the total base excretion, it will be observed that at least in these few instances the serum total base rose as the excretion increased. During the ammonium chloride periods the $\mathrm{CO}_{2}$ fell and the chlorides rose as was to be expected. During the sodium bicarbonate period the opposite was true.

TABLE 6

Data for spinal fluid electrolytes

\begin{tabular}{|c|c|c|c|c|c|c|c|c|}
\hline & 蒻 & 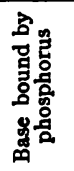 & 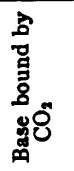 & $\begin{array}{l}\text {. } \\
\text { 영 }\end{array}$ & 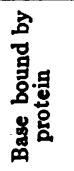 & 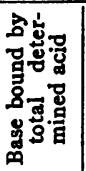 & 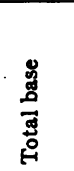 & 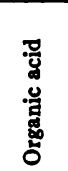 \\
\hline & $\begin{array}{l}c c . \text { of } \\
N / 10\end{array}$ & $\begin{array}{l}\text { cc. of } \\
N / 10\end{array}$ & $\begin{array}{l}\text { cc. of } \\
N ! 10\end{array}$ & $\begin{array}{l}\text { cc. of } \\
N / 10\end{array}$ & $\begin{array}{l}\text { cc. of } \\
\text { N/10 }\end{array}$ & $\begin{array}{l}c c . \text { of } \\
N / 10\end{array}$ & $\begin{array}{l}\text { cc. of } \\
N / 10\end{array}$ & $\begin{array}{l}\text { cc. of } \\
\text { N/10 }\end{array}$ \\
\hline Norn & 5.10 & 2.03 & 25.4 & 105.0 & 12.3 & 144.7 & 159 & 14.3 \\
\hline Serum water & 4.45 & 2.42 & 29.2 & 111.0 & 7.6 & 150.2 & 156 & 5.8 \\
\hline Spinal fluid & 2.45 & 1.00 & 23.2 & 127.5 & 0.02 & 121.7 & 161 & 9.3 \\
\hline
\end{tabular}

* Values calculated from normal values given by Blackfan and Hamilton (14).

The following points here seem important:

16. The blood serum before medication differed from the normal in that the total protein was low, the total base was low, and the calcium was low.

17. Ammonium chloride, sodium bicarbonate and sodium chloride ingestion raised the serum total base.

18. The total base excretion increased in the urine when the serum total base was raised.

\section{F. Spinal fluid electrolytes}

A lumbar puncture was done during period 8 , and it is of interest to compare the values for electrolytes found in the spinal fluid with those in the blood serum withdrawn at the same time. It is first 
necessary to reduce the serum values to their values per $100 \mathrm{cc}$. of serum water. The formula of Van Slyke, $\mathrm{Wu}$, and McLean (21) has been used, according to which the grams of water in 1 liter of serum equal $990-0.8 P$, where $P$ is the grams of protein per liter of serum.

The spinal fluid findings are perfectly consistent with normal values. The most important difference between spinal fluid and serum is the small amount of protein in the spinal fluid. This is compensated for by increased chlorides on the anion side. The calcium in spinal fluid is likewise low due to the low protein. As the serum protein is lowered in chronic nephritis with edema, it would appear that the serum findings approach the spinal fluid findings as a limit. The spinal fluid phosphorus, as has been repeatedly shown in this laboratory ${ }^{6}$, is lower than serum phosphorus, apparently in order to keep the same ratio of $\mathrm{Ca}$ to $\mathrm{P}$ found in the blood and in the bones.

The following observations then seem important:

19. The spinal fluid electrolytes were normal.

20. The serum findings differed from normal serum findings very much as spinal fluid findings differ from serum findings only to a lesser degree.

21. The ratio of calcium to phosphorus in the spinal fluid was approximately the same as that in the blood, a relationship which we have observed in normal subjects.

It will be unnecessary to discuss all the findings here as this would lead to considerable repetition. Three points however seem worthy of emphasis.

The pathological physiology of the fixed base metabolism in chronic nephritis with edema has many points in common with that of the calcium metabolism. Thus the urinary excretion of both is low without there being any compensatory increased fecal excretion; both are low in the blood, possibly accounting for the low urinary excretion; and ammonium chloride ingestion increases the urinary excretion of both and probably raises the serum values of each.

It seems fairly well established by the work of Blackfan and Hamilton (14) that the serum total base is lowered in chronic edema. This is corroborated in the present study. It is suggested from this study

'Unpublished data. 
that agents which tend to raise the lowered serum base value toward normal increase the total base excretion in the urine. In a recent contribution by Linder (24) it is of interest that one of the two cases of hydremic nephritis (case VII) had an initial total base in the serum of $135 \mathrm{cc}$. of $\mathrm{N} / 10$ per $100 \mathrm{cc}$., which rose to $145 \mathrm{cc}$. of N/10 under hydrochloric acid therapy. All this of course suggests that the low output of base is due to the serum base being below the threshold of kidney excretion.

The most surprising thing to us in this investigation was the response to sodium bicarbonate ingestion. It is true that the patient did become more edematous but much less so than we had expected. It would seem that the ingestion of large amounts of sodium bicarbonate likewise raises the serum base to the normal threshold of kidney excretion with a resulting increased base excretion. Our findings support the recent work of Osman (25) (26) who found that on the administration of very large doses of alkali to such patients, there was at first an increase of edema until a critical point was reached when there occurred an extraordinary diuresis.

\section{SUMMARY}

The total acid-base balance of the urine, the fixed base, calcium and phosphorus balances of the urine and feces, frequent determinations of the serum electrolytes, and one simultaneous determination of the spinal fluid and blood serum electrolytes, have been made on a mild case of chronic nephritis with edema during twelve three day periods on a constant intake in order to determine the effect of sodium chloride, ammonium chloride, and sodium bicarbonate ingestion.

\section{APPENDIX}

The patient was a 35 year old married German woman who was admitted to the Massachusetts General Hospital on February 24, 1927 complaining of generalized edema.

The past history was unimportant except for measles and chicken pox in childhood, an attack of tonsillitis at the age of 15 , and since then occasional sore throats.

The present illness started fifteen years ago with slight swelling of the ankles at the end of the day. This swelling gradually became more extensive. Six months before admission she noted swelling of the face.

Physical examination showed massive edema of the legs and slight edema over 
the sacrum. The blood pressure was $130 / 80$. The heart was within normal limits.

The urine examination showed a large amount of albumin and a normal sediment. The specific gravity varied between 1.005 and 1.015 . The phenolsulphophthalein test showed a normal excretion of the dye. The red blood cells were $4,800,000$ and the white cells 8,600 per cubic millimeter. The blood non-protein nitrogen was $25 \mathrm{mgm}$. per $100 \mathrm{cc}$. The serum protein was 4.28 grams per $100 \mathrm{cc}$. with a serum albumin of 2.3 grams per $100 \mathrm{cc}$. The blood cholesterol was 222 mgm. per $100 \mathrm{cc}$. The basal metabolism was minus 3 per cent.

The impression was that this patient was suffering from a rather mild and quite stationary form of chronic nephritis of the nephrotic type.

A letter from the patient dated June 19, 1928 states that her condition has remained stationary during the intervening year.

\begin{tabular}{|c|c|c|c|c|}
\hline \multicolumn{5}{|c|}{ Diet } \\
\hline Food substance & Weight & Protein & Fat & $\begin{array}{l}\text { Carbo- } \\
\text { hydrate }\end{array}$ \\
\hline & grams & & & \\
\hline Bread, salt free.. & 100 & 8.0 & 2.1 & 53.2 \\
\hline Butter fat....... & 40 & & 40.0 & \\
\hline Sugar.... & 30 & & & 30.0 \\
\hline Apple (raw) . & 200 & 0.6 & 1.0 & 27.0 \\
\hline Orange juice..$\ldots \ldots \ldots \ldots \ldots$ & 80 & & & 8.64 \\
\hline Banana $\ldots \ldots \ldots \ldots \ldots \ldots$ & 100 & 1.1 & 0.6 & 21.0 \\
\hline Steak.... & 150 & 31.95 & 12.0 & \\
\hline Potato....... & 100 & 1.9 & 0.1 & 18.1 \\
\hline Corn $\ldots \ldots \ldots \ldots \ldots \ldots$ & 100 & 2.8 & 1.2 & 19.0 \\
\hline Tomatoes (raw). & 100 & 1.2 & 0.2 & 4.0 \\
\hline Chicken (white). & 30 & 6.45 & 0.75 & \\
\hline & $c c$. & & & \\
\hline Coffee. & 200 & & & \\
\hline Tea........ & 400 & & & \\
\hline Total. & & 54.00 & 57.95 & 180.94 \\
\hline
\end{tabular}

Total calories, 1461.

\section{BIBLIOGRAPHY}

1. Widal, F., and Javal, A., Bull. et Mém. Soc. Méd. d. Hôp. de Paris, 1903, xx, 733. La cure de déchloruration.

2. Blum. L., Verhandl. d. Cong. f. inn. Med., Wisb., 1909, xxvi, 122. Über die Rolle von-Salzen bei der Entstehung von Oedemen.

3. Meyer, L. F., and Cohn S., Ztschr. f. Kinderh., 1911, Orig., ii, 360. Klinische Beobachtungen und Stoffwechselversuche über die Wirkung verschiedener Salze beim Säugling. 
4. Schultz, E., Ztschr. f. klin. Med., 1918, lxxxvi, 111. Klinische Beobachtungen über Nierenentzündung bei Kriegsteilnehmern.

5. Blum, L., Aubel, E., and Hausknecht, R., Bull. et. Mém. Soc. Méd. d. Hôp. de Paris, 1922, xlvi, 206. L'action diurétique des sels de calcium dans la néphrite avec oedèmes.

6. Haldane, J. B. S., Hill, R., and Luck, J. M., J. Physiol., 1923, lvii, 301. Calcium Chloride Acidosis.

7. Gamble, J. L., Ross, G. S., and Tisdall, F. F., Am. J. Dis. Child., 1923, xxv, 455. Studies of Tetany. I. The Effect of Calcium Chloride Ingestion on the Acid-Base Metabolism of Infants.

8. Haldane, J. B. S., J. Physiol., 1925, lv, 265. Experiments on the Regulation of the Blood's Alkalinity.

9. Keith, N. M., Barrier, C. W., and Whelan, M., J. Am. Med. Assoc., 1924, lxxxiii, 666. Treatment of Nephritis and Edema with Calcium.

10. Gamble, J. L., Blackfan, K. D., and Hamilton, B., J. Clin. Invest., 1925, i, 359. A Study of the Diuretic Action of Acid Producing Salts.

11. Epstein, A. A., Am. J. Med. Sci., 1917, cliv, 638. Concerning the Causation of Edema in Chronic Parenchymatous Nephritis: Method for Its Alleviation.

12. Epstein, A. A., Med. Clin. N. Amer., 1920, iv, 145. Clinical Types of Chronic Parenchymatous Nephritis-Their Treatment and Results.

13. Salvesen, H. A., and Linder, G. C., J. Biol. Chem., 1923, lviii, 617. Observations on the Inorganic Bases and Phosphates in Relation to the Protein of Blood and Other Body Fluids in Bright's Disease and in Heart Failure.

14. Blackfan, K. D., and Hamilton, B., Bull. Johns Hopkins Hosp., 1927, xli, 322: Study of the Inorganic Constituents of the Serum in Children with Acute Nephritis.

15. Bauer, W. and Aub, J. C., J. Am. Diet. Assoc., 1927, iii, 106. Studies of Inorganic Salt Metabolism. I. The Ward Routine and Methods.

16. Gamble, J. L., Ross, G. S., and Tisdall, F. F., J. Biol. Chem., 1923, lvii, 633. Metabolism of Fixed Base during Fasting.

17. Bauer, W., Albright, F., and Aub, J. C., J. Clin. Invest., 1929, vii, 75. Studies of Calcium and Phosphorus Metabolism. II. The Calcium Excretion of Normal Individuals on a Low Calcium Diet Including Data on a Case of Pregnancy.

18. Scriver, W. deM., J. Clin. Invest., 1928, vi, 115. Observations on the Excretion of Calcium in Two Cases of Nephrosis Treated with Parathyroid Extract.

19. Gamble, J. L., J. Biol. Chem., 1922, li, 295. Carbonic Acid and Bicarbonate in Urine.

20. Fitz, R., Alsberg, C. L., and Henderson, L. J., Am. J. Physiol., 1907, xviii, 113. Concerning the Excretion of Phosphoric Acid During Experimental Acidosis in Rabbits. 
21. Van Slyke, D. D., Wu, H., and McLean, F. C., J. Biol. Chem., 1923, lvi, 765. 1. Studies of Gas and Electrolyte Equilibria in the Blood. V. Factors Controlling the Electrolyte and Water Distribution in the Blood.

22. Peters, J. P., Bulger, H. A., Eisenmen, A. J., and Lee, C., J. Biol. Chem., 1926, lxvii, 141. Total Acid-Base Equilibrium of Plasma in Health and Disease. I. The Concentration of Acids and Bases in Normal Plasma.

23. Henderson, L. J., Am. J. Physiol., 1908, xxi, 427. The Theory of Neutrality Regulation in the Animal Organism.

24. Linder, G. C., Quart. J. Med., 1927, xx, 285. The Effect of Mineral Acid on Acid-Base Regulation in Health and in Nephritis.

25. Osman, A. A., Guy's Hosp. Rep., 1926, lxxvi, 412. Preliminary Observations on the Treatment of Nephritis with Oedema by Means of Large Doses of Alkalies.

26. Osman, A. A., Guy's Hosp. Rep., 1927, lxxvii, 386. Studies in Bright's Disease: The Use of Alkalies in Treatment of Bright's Disease and Their Prophylactic Value in This and Other Conditions Associated with Impairment of Renal Function. 